\title{
The Relations between Scientific Epistemological Beliefs and Goal Orientations of Pre-Service Teachers
}

\author{
Gamze Inan Kaya \\ Correspondence: Gamze Inan Kaya, Istanbul University, Hasan Ali Yucel Education Faculty, Educational Sciences \\ Department, Turkey.
}

Received: July 19, 2017

Accepted: August 14, 2017

Online Published: August 28, 2017

doi:10.11114/jets.v5i10.2547

URL: https://doi.org/10.11114/jets.v5i10.2547

\begin{abstract}
The purpose of this study was to investigate the relations between pre-service teachers' scientific epistemological beliefs and goal orientations in 2X2 framework. Scientific epistemological beliefs are domain-specific views of people about nature and acquisition of scientific knowledge, how scientific knowledge is produced, how reliable and valid that knowledge is and how it is shared. Participants were 484 pre-service teachers and $284(59 \%)$ of them were attending to education faculty and $198(41 \%)$ of them were graduates who attended teaching certificate program. Scientific epistemological beliefs predicted both mastery (approach-avoidance) and performance (approach-avoidance) goal orientations. The participants who viewed science from a more traditional perspective were more likely to adopt mastery-approach, mastery-avoidance, performance-approach and performance-avoidance goals, respectively. Moreover, the participants who attended and successfully completed a scientific research methods course formerly had less traditional scientific epistemological beliefs than the participants who had not attended to such a course previously. Theoretical and educational implications of the findings were discussed.
\end{abstract}

Keywords: scientific epistemological beliefs, goal orientations, pre-service teachers, domain-specific beliefs

\section{Introduction}

\subsection{Problem}

The reasons for engaging academic tasks -goal orientations- are constructed through learning experiences of students. So, investigating antecedents and correlates of goal adoption has been a crucial issue. As a central belief system, epistemological beliefs proposed to be related and have an impact on goal adoption (Bråten \& Strømsø, 2004; 2005; 2006; Paulsen, \& Feldman, 2005; Phan, 2009). The studies using the classification of Schommer (1990), demonstrated that more sophisticated epistemological beliefs may lead more adaptive goal adoption (Buehl \& Alexander, 2005; Muis \& Franco, 2009).

In general epistemological beliefs of pre-service teachers' and domain specifically their scientific epistemological beliefs may determine how do they approach and value or disregard information presented throughout their professional training (Fives \& Buehl, 2008). Teacher education programs “... engage pre-service teachers in studying research and conducting their own inquiries through cases, action research, and the development of structured portfolios about practice." and "...envision the professional teacher as one who learns from teaching rather than one who has finished learning how to teach" (Darling-Hammond, 2000, p.170). Pre-service teachers have been expected to be literate on educational research and able to conduct own research to improve their practice (Bailey \& Van Harken, 2014; King, 1991). In teacher education programs, methods courses aim to educate pre-service teachers on scientific methods (Shim, Young, \& Paolucci, 2010). In these courses, pre-service teachers become knowledgable on the methods of scientific inquiry (Darling-Hammond, Hammerness, Grossman, Rust, \& Shulman, 2005; İnan, 2011).

Scientific epistemological beliefs of teachers have been reported to affect both practice of teachers and perceptions and beliefs of their students in learning situations (Brownlee, 2001, 2003; Pamuk, 2014; Tsai, 2002, 2006). However, although the relations between epistemological beliefs of pre-service teachers and goal orientations have been studied in the literature, studies focusing on domain specific epistemological beliefs of pre-service teachers are limited. The relation between goal orientations and scientific epistemological beliefs of pre-service teachers has not been studied. This study aimed to investigate that relation and also revisit the role of successfully completing "scientific research methods" course in scientific epistemological beliefs with implications for teacher education as a scientific endeavor. 


\subsection{Epistemological Beliefs}

Personal epistemological development and epistemological beliefs concerned with the personal views of people on the nature and acquisition of knowledge (Feutch \& Bendixen, 2010; Hofer, 2001). In personal epistemology research, the same construct has been studied under different names including epistemological beliefs (Schommer, 1990, 1993), ways of knowing (Belenky et al., 1986), epistemological theories (Hofer \& Pintrich, 1997), and epistemological resources (Hammer \& Elby, 2002). The shared understanding in every model on nature of knowledge includes 'beliefs about the definition of knowledge, how knowledge is constructed, how knowledge is evaluated, where knowledge resides, and how knowing occurs' (Hofer, 2001, p. 355).

In developmental models of epistemological beliefs (e.g., Belenky et al., 1986; Perry, 1970) the construct was defined as one-dimensional and changing through developmental stages. Accordingly, on the earlier stages, the naïve beliefs on absolute truths and on the higher stages of development, sophisticated beliefs on relativity of human knowledge take place. On the absolutist stages, people report a dualistic understanding of knowledge, yet on the relativist pole knowledge was considered as tentative, personal and context-bounded (Feutch \& Bendixen, 2010; Hofer \& Pintrich, 1997). For instance, in his seminal work Perry (1970) revealed that undergraduate students epistemological beliefs changed through four stages (dualism, multiplied, relativism and commitment for relativism) over the progression of their academic course. In the dualism phase, students believed in existence of absolute truths and transmission of the absolute knowledge by an authority or expert. However in the commitment for relativism phase, thinking is relativistic and some beliefs are more committed by the knower himself.

There have been debates on uni-dimensional development of epistemological beliefs. Different from the developmental perspective, Schommer $(1990,1993)$ proposed that epistemological beliefs were multidimensional. In this multidimensional model, it was proposed that people may hold sophisticated (more relativistic) and naïve (more dualistic) beliefs simultaneously. The five-factored model of Schommer (1990) included beliefs on the source of knowledge (omniscient authority), the certainty of knowledge (certain knowledge), the structure of knowledge (simple knowledge), the stability of knowledge (innate/fixed ability) and the speed of learning (quick learning) (Schommer, 1990). According to this model, people may hold some sophisticated knowledge and naïve knowledge simultaneously. Although the multidimensional model of epistemological beliefs highly cited in the literature, it was criticized that innate/fixed ability and quick learning dimensions are mainly related to the nature of intelligence or ability and learning respectively (see Hofer \& Pintrich, 1997). Hofer and Pintrich (1997) had an integrative perspective and in their personal epistemological theories conceptualization, they proposed that epistemological development is not free of multidimensionality, instead in multidimensional model there may be different paces of epistemological development. Accordingly, they defined four interrelated dimensions that can be categorized under nature of knowledge (certainty and simplicity of knowledge) and process of knowing (justification and source of knowledge).

Domain specific epistemological beliefs have been also considered (Buehl \& Alexander, 2005; Muis, Bendixen, \& Haerle, 2006; Strømsø, Bråten, \& Samuelstuen, 2008; Topcu, 2013) and these beliefs are activated by a particular academic task or domain and work as implicit theories (Hofer \& Pintrich, 1997) on nature of knowledge affecting the motivational processes in these specific domains or tasks (Buehl, 2003). Accordingly, scientific epistemological beliefs are domain-specific views of people about nature and acquisition of scientific knowledge, how scientific knowledge is produced, how reliable and valid that knowledge is and how it is shared (Pomeroy, 1993). Positivist (empirist-traditional) and post-positivist (constructivist-non-traditional) views of science, influence people's scientific beliefs, especially the perceptions concerning the role of researcher (Gallaher, 1991). From a traditional perspective scientific knowledge is believed to be objective, empirical, based on control of nature, universal, value-free and replicable. The post-positivist arguments related to nature of scientific knowledge question the absolute objectivity, universality and value-free assumptions and focus on the constructivist and contextual aspects of scientific knowledge (Pomeroy, 1993; Tsai, 2000; Yang, 2005).

Teachers' epistemological beliefs were related to their beliefs about teaching and learning. Teaching strategies used by teachers were correlated to their sophisticated epistemological beliefs (Brownlee, 2003; Hashweh, 1996; Roth \& Weinstock, 2013). For instance, pre-service teachers reported more sophisticated epistemological beliefs over time in a qualitative analysis and they described teaching on a relational basis from a transformative (constructive) perspective (Brownlee, 2004). That is when teachers have relativistic epistemological beliefs, they think teaching is not sole transmission of knowledge instead it is a productive process. Similarly, domain-specific epistemological beliefs of teachers' on science and scientific knowledge are critical on their professional development. These beliefs influence how they approach the scientific knowledge in their profession and how they use (or produce) that professional knowledge in their practice (Ozturk \& Yilmaz-Tuzun, 2016; Tsai, 2002, 2006). Teachers' beliefs on nature of science or their scientific epistemological views, since they possibly played a role on instructional practices of teachers (Bell, Mulvey, \& Maeng, 2016; Wahbeh, \& Abd-El-Khalick, 2014), were related to scientific epistemological beliefs of their students' (Tsai, 2006; 
Pamuk, 2014). Additionally, students' perceptions of learning environments were related to teachers' scientific epistemological views (Tsai, 2000; 2006) and epistemic climate in the classroom (Muis, \& Duffy, 2013).

\subsection{Goal Orientations}

In engaging an academic task or performance situation, students pursue achievement related goals. Students' achievement goals are influenced by their belief systems (Dweck \& Legget, 1988) including personal epistemological theories (Pintrich, 2002). Achievement goals, which are cognitive representations related to success or failure and regulate behaviors of people in performance situations (Linnenbrink \& Pintrich, 2001), are also called goal orientations (Ames, 1992; Dweck, 1986; Dweck \& Legget, 1988; Elliot, 1999). Students may have different reasons (different goal orientations) in engaging an academic task.

Four types of goal orientations have been proposed in the literature: (a) mastery-approach goals emphasizing the worth of task and students pursuing these goals aim to understand and be competent on the subject (Ames, 1992); (b) performance-approach, in which students focus on their own ability and self-worth and in an academic situation they are motivated to demonstrate competence (Elliot, 1999; Pintrich, 2000, Pintrich, 2003); (c) performance-avoidance goals, students who pursue prefer to avoid performance situations since they do not want to be evaluated underachiever or incompetent when compared to others' performance (Elliot, 2005); (d) the recently added mastery-avoidant goals, in which students avoid new learning experiences due to fear of not being able to achieve on an academic task properly, forgetting previous knowledge or learning incorrectly and making mistakes (Elliot \& McGregor, 2001; Elliot, 2005; Kaplan \& Maehr, 2007).

As for the relations between behavioral, cognitive, educational outcomes and different goal orientations, mastery (-approach) goals have been reported to be most adaptive. These goals are associated with positive outcomes such as self-efficacy, persistence, challenge seeking, self-regulated learning and positive mood (Dweck \& Leggett, 1988; Elliot, 1999; Harackiewicz, Barron, Pintrich, Elliot \& Trash, 2002; Kaplan \& Maehr, 2007). Performance-approach goals have produced mixed results (Senko, Hulleman, \& Harackiewicz, 2011) including both positive outcomes such as higher grades, self-efficacy, and negative outcomes such as lack of cooperation, less persistence, self-handicapping strategies (Kaplan \& Maehr, 2007; Migley, Kaplan, \& Middleton, 2001). Besides, although positive correlations reported between academic achievement and performance-approach goal orientation, in case of an academic failure students with performance-approach orientation would have the risk of replacing approach orientation with avoidance orientation (Kaplan \& Middleton, 2002).

Avoidance goals (performance-avoidance and mastery-avoidance) have been related to negative outcomes. Performance-avoidance goals were associated with negative experiences related to academic achievement or wellbeing, including lower grades, less persistence, self-handicapping strategies, negative emotions (Kaplan, \& Middleton, 2002; Kaplan, \& Maerh, 2007). Besides, mastery-avoidance goals also produce maladaptive results (Kaplan \& Maehr, 2007; Elliot, 2005) such as test anxiety, worry, disorganized studying and lower performance improvement (Elliot \& McGregor, 2001; Van Yperen, Elliot, \& Anseel, 2009) yet these goals have been associated with some adaptive environmental strategies (Madjar, Kaplan, \& Weinstock, 2011).

\subsection{The Aim and Research Questions}

The present research was designed to investigate the relations among scientific epistemological beliefs and goal orientations of pre-service teachers, and to examine the role of domain specific epistemological beliefs on their goal orientations. Besides, the role of pre-attendance to scientific research methods course in relation to scientific epistemological beliefs was examined. On the basis of this general aim, more specific research questions pursued in this study included the following:

1. What is the relation between scientific epistemological beliefs and goal orientations of pre-service teachers?

2. Do scientific epistemological beliefs predict goal orientations of pre-service teachers?

3. Do the scientific epistemological beliefs of pre-service teachers differentiate due to attendance to a scientific methods course previously?

\section{Method}

This study utilized a correlational research design, in which the relationships among the variables of interest were investigated (Creswell, 2008).

\subsection{Participants}

The sample consisted of 484 pre-service teachers, $284(59 \%)$ of them were attending to education faculty and 198 $(41 \%)$ of them were graduates who attended teaching certificate program at Istanbul University. The sample included 
337 females and 145 males, and the participants ranged in age from 19 to 48 years, with an overall mean age of 23.69 $(\mathrm{SD}=4.1)$ at the outset of the study.

\subsection{Measures}

Scientific Epistemological Beliefs Survey (SEBS) developed by Pomeroy (1993) was utilized. The survey was translated and adapted into Turkish by Deryakulu and B1kmaz (2003). The scale had one-factor structure with 30 items. Of the 30 items, 5-pointed Likert type scale, 22 items reflecting traditional science conception was encoded positively and 8 items reflecting non-traditional science conception were encoded negatively. Internal cronbach alpha coefficient was found to be .91. The scale basically had a two-ended structure reflecting individuals' conception of science. High scores from the scale represent beliefs in traditional conception of science whereas low scores represent beliefs in non-traditional conception of science. Reliability estimate (Cronbach's alpha) for the traditional science conception items was .79 and for the items of non-traditional science conceptions, it was .57.

$2 X 2$ Goal Orientations Scale was developed based on four dimensional goal orientations; mastery-approach, mastery-avoidance, performance-approach, performance-avoidance (Akın, 2006). The questionnaire was composed of 26 statements about goal orientations that students were asked to rate on a 5-point Likert scale (1, never and 5, always). The Cronbach's alpha $(\alpha)$ internal consistency scores for 4 dimensions were mastery-approach .92, mastery-avoidance .97 , performance-approach .97 and performance-avoidance .95 . In the present study, reliability estimate (Cronbach's alpha) for the scales measuring goal orinetations were .75 for mastery-approach, .65 for mastery-avoidance, .79 for performance-approach, and .67 for performance avoidance.

\subsection{Procedure}

The measures were paper-based and they were administered in participants' ordinary classrooms by the author in the spring term of 2015 academic year. At the beginning of the questionnaire form, a short written instruction was provided and the author ensured that the participants read it carefully. In the administration phase, 507 questionnaires were collected. However, in the initial control of the data, 23 questionnaire forms were eliminated due to missed responses. The data belonging to 484 respondents were analysed by utilizing SPSS 24 statistical software.

\section{Results}

The means and standard deviations for all the measures were reported in Table 1; zero-order correlations were reported in Table 2.

Table 1. Means and standard deviations for goal orientations and scientific epistemological beliefs

\begin{tabular}{lllll}
\hline Variables & Participants & $N$ & $M$ & $S D$ \\
\hline Mastery Approach Goals & attending to education faculty & 284 & 31.1092 & 4.68424 \\
Mastery Avoidance Goals & attending teaching certificate program & 198 & 31.7071 & 4.47611 \\
& attending to education faculty & 284 & 16.1655 & 3.48709 \\
Performance Approach Goals & attending teaching certificate program & 198 & 15.8939 & 3.67788 \\
& attending to education faculty & 284 & 16.7606 & 5.31140 \\
Performance Avoidance Goals & attending teaching certificate program & 198 & 17.0505 & 5.52038 \\
& attending to education faculty & 284 & 15.1056 & 4.34584 \\
SEB & attending teaching certificate program & 198 & 14.5455 & 4.33911 \\
& attending to education faculty & 284 & 82.7007 & 6.33113 \\
& attending teaching certificate program & 198 & 82.9242 & 6.59174 \\
\hline
\end{tabular}

Note. SEB = Scientific epistemological beliefs

As can be seen in Table 2, in general, scientific epistemological beliefs were positively correlated with mastery and performance goal orientations, with correlations ranging from .34 to .09. Mastery-avoidance goals were positively related to both performance goals and performance goals were moderately correlated with each other in the same direction.

Table 2. Zero-order correlations for goal orientations and scientific epistemological beliefs

\begin{tabular}{|c|c|c|c|c|c|}
\hline Variable & 1 & 2 & 3 & 4 & 5 \\
\hline 1. Mastery Approach & - & & & & \\
\hline 2. Mastery Avoidance & $.341^{* *}$ & - & & & \\
\hline 3. Performance Approach & .047 & $.314^{* *}$ & - & & \\
\hline 4. Performance Avoidance & $-.128^{* *}$ & $.430^{* *}$ & $.526^{* *}$ & - & \\
\hline 5. SEB & $.335^{* *}$ & $.249^{* *}$ & $.093^{* *}$ & $.103^{*}$ & - \\
\hline
\end{tabular}

Note. ${ }^{*} p<\frac{5 ;^{* *} p<.01 ; \text { and }}{}{ }^{* * *} p<.001$.

Following that, basic regression equations were conducted with the goal orientation variables as outcome measures. The 
predictor for each of these equations was scientific epistemological belief measure. Scinetific epistemological beliefs measure was based on a continuum, the poles ranging between traditional scientific beliefs and constructivist (non-traditional) scientific beliefs. The results were shown in Table 3.

Table 3. Unstandardized and standardized regression coefficients for regression analyses predicting goal orientations

\begin{tabular}{|c|c|c|c|c|c|c|c|c|}
\hline \multirow[t]{2}{*}{ Predictor } & \multicolumn{2}{|c|}{ Mastery-Approach } & \multicolumn{2}{|r|}{ Mastery-Avoidance } & \multicolumn{2}{|c|}{ Performance-Approach } & \multicolumn{2}{|c|}{$\begin{array}{l}\text { Performance- } \\
\text { Avoidance }\end{array}$} \\
\hline & B & $\beta$ & B & $\beta$ & B & $\beta$ & B & $\beta$ \\
\hline SEB & .24 & $.34^{* * *}$ & .14 & $.24^{* * *}$ & .09 & $.09^{*}$ & .07 & $.10^{*}$ \\
\hline
\end{tabular}

The scientific epistemological beliefs, as predictor, explained a significant amount of the variance in mastery-approach goal orientation, $F(1,482)=60.809, p<.001, R^{2}=.11$. As for the mastery-avoidance, $F(1,482)=31.864, p<.001, R^{2}=.06$; performance-approach orientation $F(1,482)=4.186, p<.05, R^{2}=.01$ and performance-avoidance goal orientation scores, $F(1,482)=5.173, p<.05, R^{2}=.01$. very small amounts of the variance explained by the predictor.

Next, scientific epistemological beliefs in relation to previously attending to scientific research methods course were compared. Participants who completed a methods course previously had a slightly lower average in scientific epistemological beliefs $(M=82.30, S E=.34)$ than participants who attended no scientific method course formerly $(M=$ 83.64, $S E=.53$ ). This difference was significant $t(480)=-2,103, p<.05$; and, it did represent a low-sized effect $r=.10$.

\section{Discussion}

The relations between epistemological beliefs and goal orientations of pre-service teachers have been studied previously (Braten \& Stromso, 2004, 2005; Şen, Y1lmaz, \& Yurdugul, 2014; Y1lmaz-Tüzün, \& Topçu, 2008). This study examined the relations between domain specific, in this case scientific, epistemological beliefs and goal orientations and the role of scientific methods course on scientific epistemological beliefs of pre-service teachers. These findings uniquely contribute to the literature on scientific epistemological beliefs and goal orientations in several ways.

First, the findings demonstrated that pre-service teachers' scientific epistemological beliefs were positively related to their goal orientations. In scientific epistemological beliefs, higher scores indicated tendency toward traditional (positivist) science view and lower scores indicated tendency of constructivist (non-traditional) view of science. Previously, epistemological beliefs have been found to antecede mastery goals and performance (approach and avoidance) goals (Bråten \& Strømsø, 2004; 2006; Kizilgunes, Tekkaya, \& Sungur, 2009; Mason, Boscolo, Tornatora, \& Ronconi, 2013; Phan, 2009). The results of this study were consistent with the previous findings in a domain specific epistemological beliefs and 2X2 goal orientation framework. Specifically, the impact of traditional scientific view was more significant over mastery-approach goals and followed by mastery-avoidance, performance-approach and performance-avoidance goals respectively. Mastery goals adoption were reported to be related to more sophisticated epistemological beliefs (Neber \& Schommer-Aikins, 2002; Muis \& Franco, 2009; Paulsen \& Feldman, 2005). In this study, mastery-approach orientation was predicted by pre-service teachers' traditional epistemological views on science. However, in terms of scientific epistemological beliefs, constructivist view in science was related to sophisticated conceptions of learning science (Pamuk, 2014; Tsai, 1998; Tsai, Ho, Liang, \& Lin, 2011). For instance, it was revealed that teachers' scientific epistemological beliefs, teaching beliefs and instructional practices were correlated (Tsai, 2006). Teachers who had more constructivist beliefs in science tended to focus on student understanding and application of scientific concepts, while they allocated more time and supported student inquiry activities or interactive discussions among students. Whereas teachers with more traditionally oriented in scientific beliefs tended to emphasize students' test scores and spend more instructional time on teacher-directed lectures, tutorial problem practices, or in-class examinations that was counted as a more passive or rote perspective on science learning of students.

Teachers' epistemological and learning beliefs are important components of the epistemic climate of a classroom (Feucht, 2010; Muis et al., 2006). Therefore, classroom goal structures, which refer to students' perceptions of the learning environment, where mastery or performance goals were valued mostly, had an impact on personal goal orientations and how the epistemological beliefs of teachers were transferred. When teachers emphasize a mastery oriented learning environment, students were more likely to adopt personal mastery goals (Kaplan \& Maehr, 1999). Besides, teachers' mastery goal orientation and sophisticated beliefs on knowledge had significant impact on creativity-fostering teaching practices (Hong, Hartzell, \& Greene, 2009). Similarly, scientific epistemological views of teachers affected their own science teaching practices and their students' science perceptions (Tsai, 2006; Muis \& Foy, 2010) and students' scientific epistemological views were related to how they perceived their science learning environment (Tsai, 2000).

In their study that examining directly the relationship between teachers' and students' epistemic and learning beliefs 
Muis and Foy (2010), criticized the teacher training programs mainly focusing on traditional, teacher-centered beliefs in teaching and learning. They suggested pre-service teachers should be trained in more constructivist approaches and inservice support should be provided for effective implementation of constructive practices in the classrooms. Undergraduate science and science education students had less sophisticated beliefs in science when compared to non science majors implying that science major (including science education) students might spent more years in epistemological learning environments that focused on the positivist nature of scientific knowledge (Liu, \& Tsai, 2008). Similarly, in the present study, the reason why four goal orientations were explained by traditional scientific views of pre-service teachers rather than constructivist views of science might depend on their previous learning experiences in formal education that were possibly standing on the traditional-positivist definitions of science. However, a paradigmatic shift in teacher training that focus more on constructivist conceptions of scientific knowledge might lead a change in epistemological understanding of pre-service teachers.

Second, in accordance with the previous discussion, the relation between pre-service teachers' attendance of scientific research methods course and their scientific epistemological views was examined. Specifically, the participants who attended and successfully completed a scientific research methods course formerly had less traditional scientific epistemological beliefs than the participants who had not attended to such a course previously. The scientific knowledge base and scientific inquiry methods in the profession are shared concerns in teacher education. Professionals such as lawyers, doctors or teachers work on a body of technical or specialist knowledge basis. This professional knowledge has been scientifically proven and valid, and also applicable in practice. Since professionals work mostly in uncertain situations rather than routines, autonomous judgments in using this professional knowledge and acting with responsibility to sustain professional values are also significant dimensions of a profession (Hoyle \& John, 1995). Therefore, teachers like other professionals need long periods of training - significant parts of which need to go on within higher education- to understand scientific knowledge of the area, and develop "knowledge-based skills" for the conduct of the profession.

Teachers' understanding of science and scientific endeavor proposed to have a significant impact on scientific understanding and philosophy of their students (King, 1991). Therefore, promoting sophisticated epistemological views on science in teacher education suggested previously (Brownlee et al. 2001; Muis \& Foy, 2010; Shim, Young, Paolucci, 2010). As the findings of the study imply, scientific research methods course might be an influential means to utilize in sophistication of scientific epistemological views in teacher education. Especially the constructivist understanding of science may be introduced with a comprehensive research methods course that both cover positivist and post-positivist view of science and scientific inquiry simultaneously. Similarly, in teacher education adaptive goal adoption of preservice teachers may also be facilitated in constructive learning environments where adaptive epistemic climate was supported.

It should be noted that the data in the present study is correlational and causality statements is not possible. Yet, the scientific views of pre-service teachers as domain specific epistemological beliefs were tested as predictors of goal orientations in the light of the previous research (Braten, \& Strømsø, 2004; 2006; Paulsen, \& Feldman, 2005; Phan, 2009; Ricco, Pierce, \& Medinilla, 2010). There is a clear need for further research on scientific epistemological beliefs of both pre-service and inservice teachers by taking consideration in a comprehensive perspective including more correlates of personal goal orientations such as self-regulation strategies, self-efficacy beliefs and contextual variables such as classroom goal structures and classroom climate. Besides, the role of scientific research methods courses on sophistication of scientific epistemological beliefs needs to be clarified through qualitative analysis.

In summary, the present research suggests that pre-service teachers scientific epistemological beliefs preceded their goal orientations. Specifically, participants who view science from a more traditional perspective were more likely to adopt mastery-approach, mastery-avoidance, performance-approach and performance-avoidance goals, respectively. Besides, pre-service teachers who had completed research methods course previously were less likely to adopt traditional views of science. Since recently people need to acquire knowledge on fundamentals of science and be able to apply that knowledge to life situations (Bybee, 2015), science literacy has become a global issue in education and epistemic beliefs and expectations of working in a science-related career of students' have started to be inquired (e.g. in OECD, 2016). Therefore, focusing on scientific epistemological beliefs and promoting adaptive goal orientations in teacher training and utilizing effective methods courses become a fundamental issue.

\section{References}

Akın, A. (2006). 2x2 Başarı yönelimleri ölçeği: geçerlik ve güvenirlik çalışması. Sakarya Üniversitesi Eğitim Fakültesi Dergisi, 12, 1-14.

Ames, C. (1992). Classrooms: Goals, structures, and student motivation. Journal of Educational Psychology, 84(3), 261-271. https://doi.org/10.1037/0022-0663.84.3.261 
Bailey, N. M., \& Van Harken, E. M. (2014). Visual images as tools of teacher inquiry. Journal of Teacher Education, 65(3), 241-260. https://doi.org/10.1177/0022487113519130

Belenky, M. F., Clinchy, B. M., Goldberger, N. R., \& Tarule, J. M. (1986). Women's ways of knowing: The development of self, voice, and mind. New York: Basic Books.

Bell, R. L., Mulvey, B. K., \& Maeng, J. L. (2016). Outcomes of nature of science instruction along a context continuum: pre-service secondary science teachers' conceptions and instructional intentions. International Journal of Science Education, 38(3), 493-520. https://doi.org/10.1080/09500693.2016.1151960

Bråten, I., \& Strøms $\varnothing$, H. I. (2004). Epistemological beliefs and implicit theories of intelligence as predictors of achievement goals. Contemporary Educational Psychology, 29, 371-388. https://doi.org/10.1016/j.cedpsych.2003.10.001

Bråten, I., \& Strøms $\varnothing$, H. I. (2005). The relationship between epistemological beliefs, implicit theories of intelligence, and self-regulated learning among Norwegian postsecondary students. British Journal of Educational Psychology, 75, 539-565. https://doi.org/10.1348/000709905X25067

Bråten, I., \& Strøms $\varnothing$, H. I. (2006). Predicting achievement goals in two different academic contexts: A longitudinal study. Scandinavian Journal of Educational Research, 50, 127-148. https://doi.org/10.1080/00313830600575932

Brownlee, J. (2001). Epistemological beliefs in pre-service teacher education students. Higher Eduction Research and Development, 20(3), 281-291. https://doi.org/10.1080/07294360120108377

Brownlee, J. (2004). Teacher education students' epistemological beliefs: Developing a relational model of teaching. Research in Education, 72(1), 1-17. https://doi.org/10.7227/RIE.72.1

Brownlee, J. M. (2003). Paradigm shifts in pre-service teacher education students: A case study of Changes in epistemological beliefs for two teacher education students. Australian Journal of Educational \& Developmental Psychology, 3, 1-6.

Brownlee, J., Purdie, N., \& Boulton-Lewis, G. (2001). Changing epistemo- logical beliefs in pre-service teacher education students. Teaching in Higher Education, 6(2), 247-268. https://doi.org/10.1080/13562510120045221

Buehl, M. M. (2003). At the crossroads of epistemology and motivation: Modeling the relations between students' domain-specific epistemological beliefs, achievement motivation, and task performance. (Unpublished doctoral dissertation). University of Maryland, College Park.

Buehl, M. M., \& Alexander, P. A. (2005). Motivation and performance differences in students' domain-specific epistemological belief profiles. American Educational Research Journal, 42(4), 697-726. https://doi.org/10.3102/00028312042004697

Bybee, R. (2015). Scientific literacy. Encyclopedia of Science Education, 944-947. https://doi.org/10.1007/978-94-007-2150-0_178

Creswell, J. (2008). Educational research: Planning, conducting, and evaluating quantitative and qualitative research. New Jersey: Pearson: Merrill Prentice Hall.

Darling-Hammond, L. (2000). How teacher education matters. Journal of Teacher Education, 51(3), 166-173. https://doi.org/10.1177/0022487100051003002

Darling-Hammond, L., Hammerness, K., Grossman, P., Rust, F., \& Shulman, L. (2005). The design of teacher education programs. In L. Darling-Hammond and J. Bransford (Eds.), Preparing teachers for a changing world: What teachers should learn and be able to do, (pp. 390-441). Josey-Bass: A Wiley Impirint.

Deryakulu, D., \& Bıkmaz, F. H. (2003). Bilimsel epistemolojik inançlar ölçeğinin geçerlik ve güvenirlik çalışması. Eğitim Bilimleri ve Uygulama, 2(4), 243-257.

Dweck, C. S. (1986). Motivational processes affecting learning. American Psychologist, 4l(10), 1040-1048. https://doi.org/10.1037/0003-066X.41.10.1040

Dweck, C. S., \& Leggett, E. L. (1988). A social-cognitive approach to motivation and personality. Psychological Review, 95, 256-273. https://doi.org/10.1037/0033-295X.95.2.256

Elliot, A. J. (1999). Approach and avoidance motivation and achievement goals. Educational Psychologist, 34(3), 169-189. https://doi.org/10.1207/s15326985ep3403_3

Elliot, A. J. (2005). A conceptual history of the achievement goal construct. In A. J. Elliot, \& C. S. Dweck (Eds.), Handbook of competence and motivation (pp. 52-72). New York, NY: Guildford. 
Elliot, A. J., \& McGregor, H. (2001). A 2 x 2 achievement goal framework. Journal of Personality and Social Psychology, 80, 501-519. https://doi.org/10.1037/0022-3514.80.3.501

Feucht, F. C. (2010). Epistemic climate in elementary classrooms. In L. D. Bendixen \& F. C. Feucht (Eds.), Personal epistemology in the classroom: Theory, research, and implications for practice (pp. 55-93). Cambridge, UK: Cambridge University Press. https://doi.org/10.1017/CBO9780511691904.003

Feucht, F. C., \& Bendixen, L. D. (2010). Personal epistemology in the classroom: a welcome and guide for the reader. In L. D. Bendixen \& F. C. Feucht (Eds.), Personal epistemology in the classroom: Theory, research, and implications for practice (pp. 3-28). Cambridge, UK: Cambridge University Press. https://doi.org/10.1017/CBO9780511691904.001

Fives, H., \& Buehl, M. M. (2008). What do teachers believe? Developing a framework for examining beliefs about teachers' knowledge and ability. Contemporary Educational Psychology, 33(2), 134-176. https://doi.org/10.1016/j.cedpsych.2008.01.001

Gallagher, J. J. (1991). Prospective and practicing secondary school science teachers' knowledge and beliefs about the philosophy of science. Science Education, 75(1), 121-133. https://doi.org/10.1002/sce.3730750111

Hammer, D. H., \& Elby, A. (2002). On the form of personal epistemology. In B.K. Hofer and P.R. Pintrich (Eds.), Personal epistemology: The psychology of beliefs about knowledge and knowing (pp. 169-90). Mahwah, NJ: Lawrence Erlbaum Associates.

Harackiewicz, J. M., Barron, K. E., Pintrich, P. R., Elliot, A. J., \& Thrash, T. M. (2002). Revision of Achievement Goal Theory: Necessary and Illuminating. Journal of Educational Psychology, 94(3), 638-645. https://doi.org/10.1037/0022-0663.94.3.638

Hashweh, M. Z. (1996). Effects of science teachers' epistemological beliefs in teaching. Journal of Research in Science Teaching, 33(1), 47-63. https://doi.org/10.1002/(SICI)1098-2736(199601)33:1<47::AID-TEA3>3.0.CO;2-P

Hofer, B. K. (2001). Personal epistemology research: Implications for learning and teaching. Educational Psychology Review, 13(4), 353-383. https://doi.org/10.1023/A:1011965830686

Hofer, B. K., \& Pintrich, P. R. (1997). The development of epistemological theories: Beliefs about knowledge and knowing and their relation to learning. Review of Educational Research, 67(1), 88-140. https://doi.org/10.3102/00346543067001088

Hong, E., Hartzell, S. A., \& Greene, M. T. (2009). Fostering creativity in the classroom: Effects of teachers' epistemological beliefs, motivation, and goal orientation. The Journal of Creative Behavior, 43(3), 192-208. https://doi.org/10.1002/j.2162-6057.2009.tb01314.x

Hoyle, E., \& John, P. D. (1995). Professional knowledge and professional practice. Burns \& Oates.

İnan, G. (2011). Eylem araştırması: Eğitimde değiş̧imin yaratılmasında öğretmenin gücü. Celal Bayar Üniversitesi Sosyal Bilimler Dergisi, 9(2), 481-486.

Kaplan, A., \& Maehr, M. L. (1999). Achievement goals and student well-being. Contemporary Educational Psychology, 24(4), 330-358. https://doi.org/10.1006/ceps.1999.0993

Kaplan, A., \& Maehr, M. L. (2007). The contribution and prospects of goal orientation theory. Educational Psychology Review, 19, 141-184. https://doi.org/10.1007/s10648-006-9012-5

Kaplan, A., \& Middleton, M. J. (2002). Should childhood be a journey or a race?: A response to Harackiewicz et al., (2002). Journal of Educational Psychology, 94, 646-648. https://doi.org/10.1037/0022-0663.94.3.646

King, B. B. (1991). Beginning teachers' knowledge of and attitudes toward history and philosophy of science. Science Education, 75(1), 135-141. https://doi.org/10.1002/sce.3730750112

Kizilgunes, B., Tekkaya, C., \& Sungur, S. (2009). Modeling the Relations Among Students' Epistemological Beliefs, Motivation, Learning Approach, and Achievement, The Journal of Educational Research, 102(4), 243-256. https://doi.org/10.3200/JOER.102.4.243-256

Linnenbrink, E. A., \& Pintrich, P. R. (2001). Multiple goals, multiple contexts: The dynamic interplay between personal goals and contextual goal stresses. S. Volet \& S. Jarvela (Ed.), Motivation in learning contexts: Theoretical advances and methodological implications (251-269). Amsterdam: Elsevier.

Liu, S. Y., \& Tsai, C. C. (2008). Differences in the scientific epistemological views of undergraduate students. International Journal of Science Education, 30(8), 1055-1073. https://doi.org/10.1080/09500690701338901

Madjar, N., Kaplan, A., \& Weinstock, M. (2011). Clarifying mastery-avoidance goals in high school: Distinguishing 
between intrapersonal and task-based standards of competence. Contemporary Educational Psychology, 36, 268279. https://doi.org/10.1016/j.cedpsych.2011.03.003

Mason, L., Boscolo, P., Tornatora, M. C., \& Ronconi, L. (2013). Besides knowledge: A cross-sectional study on the relations between epistemic beliefs, achievement goals, self-beliefs, and achievement in science. Instructional Science, 41(1), 49-79. https://doi.org/10.1007/s11251-012-9210-0

Midgley, C., Kaplan, A., \& Middleton, M. J. (2001). Performance-approach goals: Good for what, for whom, under what circumstances, and at what cost? Journal of Educational Psychology, 93, 77-86. https://doi.org/10.1037/0022-0663.93.1.77

Muis, K. R., \& Duffy, M. C. (2013). Epistemic climate and epistemic change: Instruction designed to change students' beliefs and learning strategies and improve achievement. Journal of Educational Psychology, 105(1), 213. https://doi.org/10.1037/a0029690

Muis, K. R., \& Foy, M. J. (2010). The effects of teachers' beliefs on elementary students' beliefs, motivation, and achievement in mathematics. In L. D. Bendixen \& F. C. Feucht (Eds.), Personal epistemology in the classroom: Theory, research, and implications for practice (pp. 435-469). Cambridge, UK: Cambridge University Press. https://doi.org/10.1017/CBO9780511691904.014

Muis, K. R., \& Franco, G. M. (2009). Epistemic beliefs: Setting the standards for self-regulated learning. Contemporary Educational Psychology, 34, 306-318. https://doi.org/10.1016/j.cedpsych.2009.06.005

Muis, K. R., Bendixen, L. D., \& Haerle, F. C. (2006). Domain-generality and domain-specificity in personal epistemology research: Philosophical and empirical reflections in the development of a theoretical framework. Educational Psychology Review, 18(1), 3-54. https://doi.org/10.1007/s10648-006-9003-6

Neber, H., \& Schommer-Aikins, M. (2002). Self-regulated science learning with highly gifted students: The role of cognitive, motivational, epistemological, and environmental variables. High Ability Studies, 13, 59-74. https://doi.org/10.1080/13598130220132316

OECD (2016). PISA 2015 Results (Volume II): Policies and Practices for Successful Schools, PISA, OECD Publishing, Paris. https://doi.org/10.1787/9789264267510-en

Ozturk, N., \& Yilmaz-Tuzun, O. (2016). Pre-service Science Teachers' Epistemological Beliefs and Informal Reasoning Regarding Socioscientific Issues. Research in Science Education, 1-30. https://doi.org/10.1007/s11165-016-9548-4

Pamuk, S. (2014). Multilevel analysis of students science achievement in relation to constructivist learning environment perceptions, epistemological beliefs, self-regulation and science teachers characteristics. (Unpublished doctoral dissertation). Middle East Technical University, Ankara, Turkey.

Paulsen, M. B., \& Feldman, K. A. (2005). The conditional and interaction effects of epistemological beliefs on the self-regulated learning of college students: motivational strategies. Research in Higher Education, 46(7), 731-768. https://doi.org/10.1007/s11162-004-6224-8

Perry, W. G. Jr. (1970). Forms of intellectual and ethical development in the college years: A scheme. New York: Holt, Rinehart, and Winston.

Phan, H. P. (2009). Amalgamation of future time orientation, epistemological beliefs, achievement goals and study strategies: Empirical evidence established. British Journal of Educational Psychology, 79, 155-173. https://doi.org/10.1348/000709908X306864

Pintrich, P. R. (2000). An achievement goal theory perspective on issues in motivation terminology, theory, and research. Contemporary Educational Psychology, 25, 92-104. https://doi.org/10.1006/ceps.1999.1017

Pintrich, P. R. (2002). Future challenges and directions for theory and research on personal epistemology. In B.K. Hofer and P. R. Pintrich (Eds.), Personal epistemology: The psychology of beliefs about knowledge and knowing (389414). Mahwah, NJ: Lawrence Erlbaum Associates.

Pintrich, P. R. (2003). Motivation and classroom learning. In W. M. Reynolds \& G. E. Miller (Eds). Handbook of psychology: Educational psychology (103-122). New York, NY: Wiley. https://doi.org/10.1002/0471264385.wei0706

Pomeroy, D. (1993). Implications of teachers' beliefs about the nature of science: Comparison of the beliefs of scientists, secondary science teachers, and elementary teachers. Science Education, 77(3), 261-278. https://doi.org/10.1002/sce.3730770302

Ricco, R., Pierce, S. S., \& Medinilla, C. (2010). Epistemic beliefs and achievement motivation in early adolescence. 
Journal of Early Adolescence, 30, 350-340. https://doi.org/10.1177/0272431609333299

Roth, G., \& Weinstock, M. (2013). Teachers' epistemological beliefs as an antecedent of autonomy-supportive teaching. Motivation and Emotion, 37(3), 402-412. https://doi.org/10.1007/s11031-012-9338-x

Schommer, M. (1990). Effects of beliefs about the nature of knowledge on comprehension. Journal of Educational Psychology, 82(3), 498-504. https://doi.org/10.1037/0022-0663.82.3.498

Schommer, M. (1993). Epistemological development and academic performance among secondary students. Journal of Educational Psychology, 85(3), 406-411. https://doi.org/10.1037/0022-0663.85.3.406

Sen, S., Yilmaz, A., \& Yurdagül, H. (2014). An Evaluation of the Pattern between Students' Motivation, Learning Strategies and Their Epistemological Beliefs: The Mediator Role of Motivation. Science Education International, 25(3), 312-331.

Senko, C., Hulleman, C. S., \& Harackiewicz, J. (2011). Achievement goal theory at the crossroads: Old controversies, current challenges and new directions. Educational Psychologist, 46, 26-47. https://doi.org/10.1080/00461520.2011.538646

Shim, M. K., Young, B. J., \& Paolucci, J. (2010). Elementary teachers' views on the nature of scientific knowledge: A comparison of inservice and pre-service teachers approach. Electronic Journal of Science Education, 14(1), 1-18.

Strømsø, H. I., Bråten, I., \& Samuelstuen, M. S. (2008). Dimensions of topic-specific epistemological beliefs as predictors of multiple text understanding. Learning and Instruction, 18(6), 513-527. https://doi.org/10.1016/j.learninstruc.2007.11.001

Topcu, M. S. (2013). Preservice Teachers' Epistemological Beliefs in Physics, Chemistry, and Biology: A Mixed Study. International Journal of Science and Mathematics Education, 11(2), 433-458. https://doi.org/10.1007/s10763-012-9345-0

Tsai, C. C. (1998). An analysis of scientific epistemological beliefs and learning orientations of Taiwanese eighth graders. Science Education, 82, 473-489. https://doi.org/10.1080/001318800363836

Tsai, C. C. (2000). Relationships between student scientific epistemological beliefs and perceptions of constructivist learning environments. Educational Research, 42, 193-205. https://doi.org/10.1080/09500690110049132

Tsai, C. C. (2002). Nested epistemologies: Science teachers' beliefs of teaching, learning, and science. International Journal of Science Education, 24(8), 771-783.

Tsai, C. C. (2006). Teachers' scientific epistemological views: The coherence with instruction and students' views. Science Education, 91(2), 222-243. https://doi.org/10.1002/sce.20175

Tsai, C. C., Ho, H. N. J., Liang, J. C., \& Lin, H. M. (2011). Scientific epistemic beliefs, conceptions of learning science and self-efficacy of learning science among high school students. Learning and Instruction, 21(6), 757-769. https://doi.org/10.1016/j.learninstruc.2011.05.002

Van Yperen, N. W., Elliot, A. J., \& Anseel, F. (2009). The influence of mastery - avoidance goals on performance improvement. European Journal of Social Psychology, 39(6), 932-943. https://doi.org/10.1002/ejsp.590

Wahbeh, N., \& Abd-El-Khalick, F. (2014). Revisiting the Translation of Nature of Science Understandings into Instructional Practice: Teachers' nature of science pedagogical content knowledge. International Journal of Science Education, 36(3), 425-466. https://doi.org/10.1080/09500693.2013.786852

Yang, F. Y. (2005). Student views concerning evidence and the expert in reasoning a socio-scientific issue and personal epistemology. Educational Studies, 31, 65-84. https://doi.org/10.1080/0305569042000310976

Yilmaz-Tuzun, O., \& Topcu, M. S. (2008). Relationships among pre-service science teachers' epistemological beliefs, epistemological world views, and self - efficacy beliefs. International Journal of Science Education, 30(1), 65-85. https://doi.org/10.1080/09500690601185113

\section{Copyrights}

Copyright for this article is retained by the author(s), with first publication rights granted to the journal.

This is an open-access article distributed under the terms and conditions of the Creative Commons Attribution license which permits unrestricted use, distribution, and reproduction in any medium, provided the original work is properly cited. 